\title{
ラマン分光法による超臨界水の水素結合構造の検討 An In Situ Laser Raman Spectroscopy Study on the Structure of Supercritical Water
}

\author{
生島 豊 \\ Ikushima, Yutaka
}

\begin{abstract}
The structure of high-pressure and supercritical water has been examined up to $510{ }^{\circ} \mathrm{C}$ and $40 \mathrm{MPa}$ with in situ laser Raman spectroscopy. At $24 \mathrm{MPa}$ or below, the hydrogen bonding in the tetrahedral configuration becomes weaker and this structure breaks with increasing temperature, especially near the critical temperature, above which small clusters like dimers are dominant species. At higher pressures, a similar but slight structural change occurs; however, the tetrahedral configuration is predominant above the critical temperature. Near the critical point, short-lived tetrahedral configurations are significantly increased and coexist with dimer and monomer structures at equilibrium.
\end{abstract}

[Supercritical water, laser Raman spectroscopy, structure, hydrogen bonds]

\section{1.はじめに}

二酸化炭素は超臨界状態でも無極性でその本質は基 本的には変化しないのに対して、水は超臨界状態に変 化すると常温の水とは全く異なる性質を有してくるこ とはよく知られている。たとえば、常温大気压下の水 の誘電率は80程度であるが、臨界温度付近では超臨界 水の誘電率は 2 20程度であることから、水の誘電率 は温度、圧力により連続的かつ広範に制御できる。こ のことから超臨界水中には芳香族系化合物のような極 性の低い有機物や、さまざまな気体も溶解でき、その 工学的な価值は非常に大きい。かくて、このような超 臨界水の特性を利用した有毒物質の酸化分解反応 (SCWO)に世界的な注目が集まっている。これは超臨界 水中には多くの有害有機物（たとえば、含塩素芳香族 化合物）、空気、酸素のような酸化剂が容易に溶解 し、酸化分解（燃焼）が可能になるからである。著者 らも過酸化水素を酸化剂としたSCWOにより Polychlorinated biphenyl(PCB)の完全分解にほぼ成功して いる $[1,2]$ 。さらに、合成反応、還元反応、熱分解反 応や脱水反応などの熱化学反応の反応媒体としてもそ の応用の可能性は極めて広く（たとえば $[3,4]$ の総 説）、超臨界水の反応溶媒としての将来性を明示して いる。

超臨界水の工学的応用は上記に示したSCWOをはじ
めとし実施例が多く、実用化に向けた研究も盛んに行 われている。しかし、その反面ミクロな視点で超臨界 水をとらえた基礎研究は極めて少なく、SCWOの反応 機構も推察の域を出ていない [5]。その反応性とそれ を支配している超臨界水のミクロな溶液構造の因果関 係は全く明らかではない。超臨界二酸化炭素で報告さ

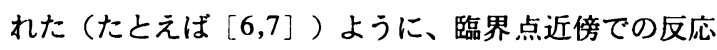
基質同士の会合効果や溶媒和の変化、溶媒分子の再配 列現象が反応速度や選択性に影響を及ぼしている可能 性もあり、加えて超臨界水を反応場とする原子組み替 え反応の速さと収率を効率的に制御する上でも、反応 場としての超臨界水の構造とダイナミックスの役割と その原理を解明するとともに、超臨界溶液化学そのも のを分子レベルで実験的に考察することは不可欠であ る。

溶液のミクロ構造は、それがもつマクロな性質、た とえば沸点、融点、誘電率などの物理化学的物性值に 反映されるか、溶液はミク口的には均一な構造をなし ておらず、分子間相互作用、分子の熱運動との釣り合 いの中でcybotactic領域で不均一な構造を取り、反応性 と密接な関係を持つことが明らかになってきた $[8]$ 。 超臨界水に関わるミクロ因子を明らかにするために は、X線・中性子回折法による溶液構造の研究 [9]、 
NMR法を主体とするダイナミックスの研究 [10] 、ラ マン散乱法等による振動スペクトルの研究により実験 的に検証することが最良であるが、いずれも高温・高 圧力下でのその場測定法を実現しなければならず大き な困難を伴う。著者は、超臨界水のような高温・高圧 力下での測定に適し、水素結合に代表される超臨界水 のミクロ構造やそのダイナミックスを考察する実験的 基盤を提供でき、化学反応機構を解明するためにも有 力な手段となり得る高温・高圧レーザーラマン分光シ ステムの開発に成功した。

本稿では、新たに開発した本システムを用いて、超 臨界水のO-H対称伸縮振動（ $\nu_{1} ）$ 或いはO-H変角振動 （ $\nu_{2}$ )を中心に検討を行った結果、臨界点付近での特 異な温度依存性などいくつかの興味深い知見を見いだ したので、報告する。

\section{2. 高温・高殴レーザーラマン分光システム}

\section{1 ラマン分光法の特緗}

高温・高压測定への適用性を含めてラマン分光法の 特徵を簡単に述へる。(1)ラマン分光法は赤外分光法 ( IR）と異なり、入射フォトンと散乱フォトンの 2 光子 過程で測定が行われるため、そのエネルギーや偏光を 制御することによって共鳴効果や分子の対称性に関す る直接的な知見が得られる。(2)励起光源として可視紫 外領域のレーザー光を用いるため、耐温度、耐圧性の 強いサファイアを光学セルの空材として利用できる。 この点、普通赤外領域で光の透過が前提であるIRは利 用できないし、超臨界二酸化炭素中でのin situ測定で 使用した $Z \mathrm{n} \mathrm{S}$ も耐温度性が弱く使用できない。加え て、ダイアモンドについても500 ${ }^{\circ} \mathrm{C}$ 以上で炭化するお それがあり、絶対とはいえない。(3)セルの光路長を配 慮する必要がないので、光学セルの設計が比較的容易 である。しかし、上記のラマン分光法にも蛍光の問題 など克服すべきいくつかの問題がある。

\section{2 システムの概略}

Fig.1に、使用した流通式の高温・高圧レーザーラマ ン分光システムの概略図を示した。測定方法は、まず 高純度蒸留水 ( 3 回蒸留) を室素ガスで十分バブリン グし脱気した後、フィルターを通し、通常の高速液ク 口用ポンプを用いて連続的に送液した。圧力は背圧弁 によって $0.1 \mathrm{MPa}$ 精度で、また温度はマントルヒー ター型の加熱炉を作成し、温度コントローラーによっ て制御した。温度の較正は気液共存二相領域での任意 の温度（たとえば $350^{\circ} \mathrm{C}$ ) で圧力を測定し、NBC/NRC

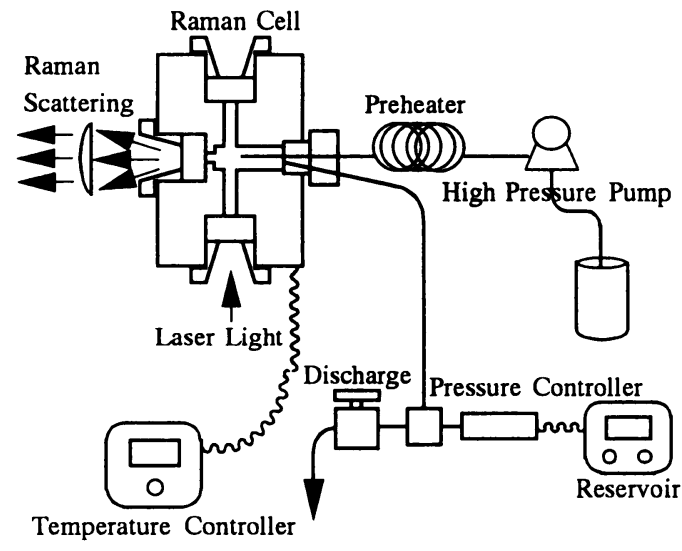

Fig.1. Schemetic diagram of the apparatus:

Tableを参照して飽和点での既知温度と比較することに よって行った。Fig. 2に本研究で測定したレィバンドの 極大值の振動数 $(\nu$ max $)$ の温度依存性を示した。M asten ら［11］による測定結果（の）も示したが、この温度 領域で著者の結果とほぼ一致した。このことは本研究 での測定温度の精度の妥当性を示唆している。

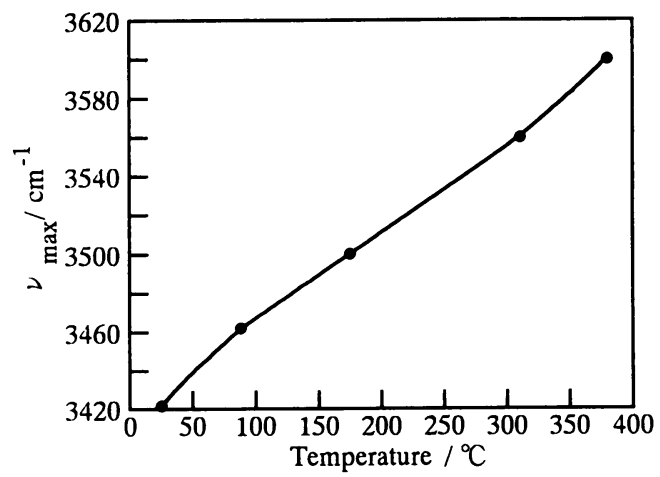

Fig.2. Raman shift of $\nu_{1}$ frequencies measured in this study(-) and by Masten et al.(O)

Fig.3は高温・高压セルの断面図である。セルの材質 はインコネル製で内容積 $0.5 \mathrm{ml}$ 、空材としてサファイ アを使用した。試料からの散乱光はレーザー進行方向 に対して90 の散乱光を検出した。温度はレーザー光 があたるセル中心部の直下を測定し、セル温度とし た。励起光源の紫外可視レーザーとして、アルゴンイ オン $(\mathrm{Ar}+)$ レーザーを使用し、レーザーパワー $150 \mathrm{~mW}$ 、 励起波長として488 nm、露光時間10秒で測定した。検 出器として時間分解測定もできる電荷結合素子(CCD) を-196 ${ }^{\circ} \mathrm{C}$ に冷却して使用した。また、前置分光器とリ 
ジェクションフィルターを装備したポリクロメーター

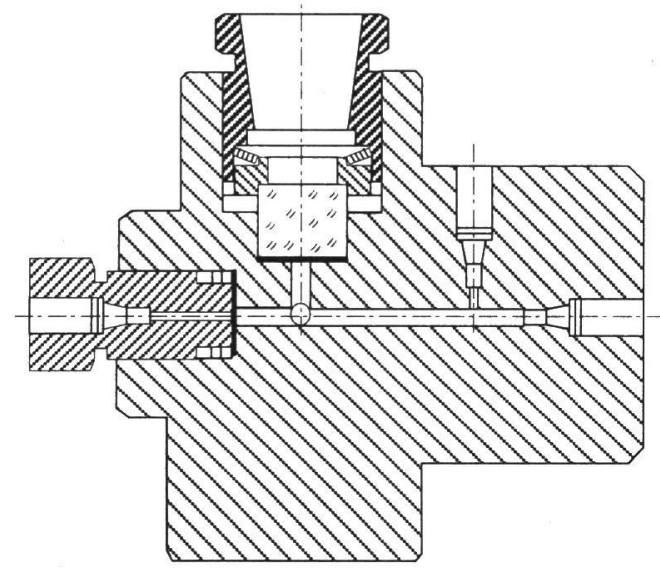

Fig.3. Vertical sectional view of high-pressure and hightemperature cell.

によりレーリー散乱光を効率よく除くことにより、 $\mathrm{CCD}$ 効率を向上させた。

\section{3. 超臨界水のラマンスペクトル}

\section{1 スペクトルの温度依存性}

Fig. 4 は、压力 $40 \mathrm{MPa}$ 一定で50、350、375、450 ${ }^{\circ} \mathrm{C}$ で測定した水のO-Hの $\nu_{1}$ スペクトルを、バンド分解の 計算結果とともに示した（点線が実験值、実線が計算 値）。なお、本研究でのGaussian curve fitting 計算にお ける相関係数はほぼ 1であった。水のラマンスペクト ルでは、 $\nu_{1}$ (たとえば、水のダイマー構造の振動数は $3652 \mathrm{~cm}^{-1}$ に、モノマー構造のそれは3656.6 $\mathrm{cm}^{-1}$ である

[12、13]。）強度は非常に強いが、3756 $\mathrm{cm}^{-1}$ の逆対 称伸縮振動 $\left(\nu_{3}\right)$ のラマン強度は非常に弱い。 $\nu_{3}$ の ラマンスペクトルを検出するためにはスリット幅 15 $\mathrm{cm}-1$ 以上で5-10 Wのレーザー出力が必要なことが報告 されている [14]。かくて、ラマンスペクトルにおけ るレ 1 振動数の詳細な解析は水分子の特性を理解する上 で非常に有効である。

Fig. 4に示したように50 ㄷでのレ1スペクトルは非常 にブロードで、 $\nu_{\max }$ は3220 $\mathrm{cm}^{-1}$ であったが、温度の增 加とともにブルーシフトし、450 ${ }^{\circ} \mathrm{C} て ゙ は 3620 ~ \mathrm{~cm}^{-1}$ に達 した。また、それにともないピークは鋭くなり、半值 幅(fwhh)が著しく減少し、3220 $\mathrm{cm}^{-1}$ のピークは消失 した。半值幅(fwhh)が隇少したことは、水分子のネッ トワークの形成に支配的であった水素結合構造が温度 の增加により失われたことを示し、このため四面体構 造を形成する水分子内のO-H結合が強くなりその振動 数がブルーシフトした。

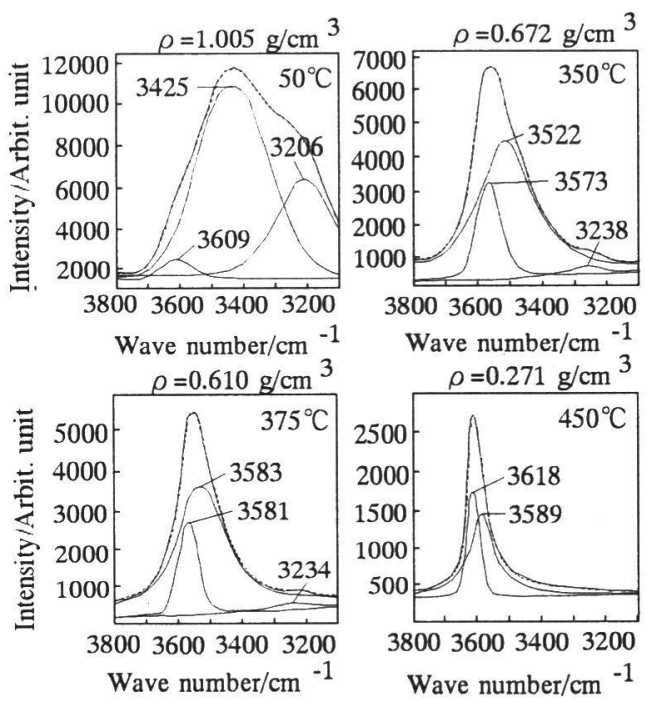

Fig.4. Examples of Raman spectra at a constant pressure of $40 \mathrm{MPa}$. Dots are experimental data and solid lines correspond to deconvoluted Gaussians and their sum.

\section{2 バンド分解}

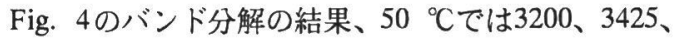
$3610 \mathrm{~cm}^{-1}$ 付近に、350、375 ${ }^{\circ} \mathrm{C}$ では3230、3500、3600

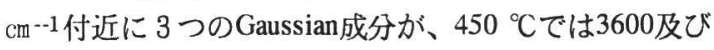
$3620 \mathrm{~cm}^{-1}$ につのピークを同定できた。また、低温域 で同定できた $3425 \mathrm{~cm}^{-1}$ 付近の成分に代わって、高温で は3500 $\mathrm{cm}^{-1}$ 以上にピークが現れた。以上の結果より、 本研究では、室温の水から超臨界水までのン1振動子之 して、（1）3220、（2）3420、（3 3 320、（4) 3600、（5）>3615 $\mathrm{cm}^{-1}$ の 5 つGaussian成分を特定し た。

上記成分のアサインについて次のように考察した。 温度の上昇により水素原子が不安定になるとOH振動子 の再配向が起こり、水素結合は直線から歪んで、水素 原子が四面体構造内の 2 つの酸素受容体の中間に位置 する、いわゆるbifurcat edな状態を形成することが考え られる。このときのO-H間の距離は2.4 AでWan der waals径の $2.7 \AA$ より短く、確実にO-H間で相互作用して いる。最近の中性子回折実験の結果 [15] では、得ら 


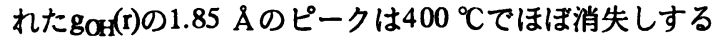
か、代わりにbifurcatedな水素結合(BHB)に相当する2.2 ̊に肩ピークが現れることが確認されている。水素原 子の配位数の增加は明らかに $\nu_{1}$ 振動数をブルーシフト させることから、3420 cm-1のバンドがBHBに対応する と考えられた。このアサインは以前の報告 [14] に よっても支持されている。

臨界温度以上では3600 cm-1あるいはそれ以上の振動 数のレ バンドが観察されることから、高温での温度効 果がBHBをさらに再配向させる可能性が強い。すなわ ち、BHBを形成する四面体構造においてbifurcat edの状 態に無い水素結合も不安定になり、四面体の面上に移 動する。そのときの水素原子はWan der waals径の外側 に位置（近接の酸素原子からの距離は3.4 $\AA$ ）するの で、水素結合を形成しない。以後この四面体構造を NHB(Non-hydrogen-bond)と呼ぶことにする。このとき、 水分子の $\angle \mathrm{H}-\mathrm{O}-\mathrm{H}$ は 104.5 ○ であるので、NHB構造にお いては、もう一方のO-H結合はBHBのみから形成され ることは容易に理解されよう。

以上より、臨界温度或いはそれ以下ではBHBあるい はNHBが主要な構造をとり、両者が共存する平衡状態 を形成していることが考えられた。しかし、それ以上 の高温下ではほぼNHB構造を形成し、40MPaでは450 ${ }^{\circ} \mathrm{C} て ゙ も$ 四面体構造を保ち水素結合のネットワークは維 持されていることが分かった。

\section{4. 臨界点付近での水来結合粸造}

\section{1 O-H対称伸椯振功}

一つの関心事に、超臨界状態とりわけ臨界点付近で の水素結合構造はどのようなものか。四面体構造は維 持されているのか。という問題がある。Fig.5にほぼ臨 界圧力の22.1 MPaでのレ 1成分(2)と(4)のラマン強度と fwhhの温度 (密度) 依存性を示した。通常の水の直線 状(O-H-O)水素結合に相当する成分(1)については $350^{\circ} \mathrm{C}$ 以上でほぼ消失することが分かった。温度が増加する につれて、成分(2)と(4)のバンドはともに狭くなるの で、水素結合のネットワークが消失してくることは明 らかである。この挙動はよく知られている $[16]$ が、 各成分のラマン強度の温度依存性は非常に興味深く、 ほぼ臨界温度付近(375 380 $\left.{ }^{\circ} \mathrm{C}\right)$ で両成分とも極大值を 示すことが判明した。以前の超臨界水のX線回折研究 において、温度の增加に伴い臨界温度以下でほほ消失 していたgoo(r)の4.5 $\AA$ のピーク（水分子の四面体構造 の頂点間の長さに対応する）か、臨界温度を超えると
再び現れることが報告されている [17] が、の温度 依存性はFig.5に示したそれと非常に似ている。このこ とから、本研究で観察された臨界温度でのラマン強度 の增大は四面体構造の“再生”によるものと推測され た。

Density $/ \mathrm{g} \mathrm{cm}^{-3}$

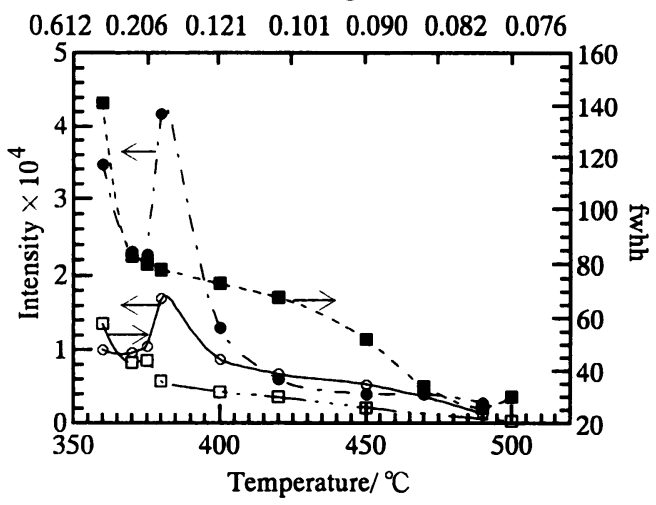

Fig.5. The intensity(area) and half-width(fwhh) of the bands (2) and (4) as functions of temperature and density at the critical pressure of $22.1 \mathrm{MPa}$. $(\boldsymbol{O}, \square)$ : (2) near $3400 \mathrm{~cm}^{-1},(\bigcirc, \square):(4)$ near $3600 \mathrm{~cm}^{-1}$.

Fig. 6に20.0, 22.1，23.5, 30.0, 40.0 MPaでの成分 （4）のレ $\max$ の温度依存性を示した。温度が增加する につれて、いずれの圧力下でも波数は高波数側にシフ トし、とりわけ23.5 MPa以下の圧力下では臨界温度付 近でその傾向が顕著であるか、これにより臨界点付近 では水素結合力が著しく弱まることが明らかになっ た。また、予想された通り、一定温度下では高圧力 (高密度) になるほど、低波数（低振動数）にシフト した。

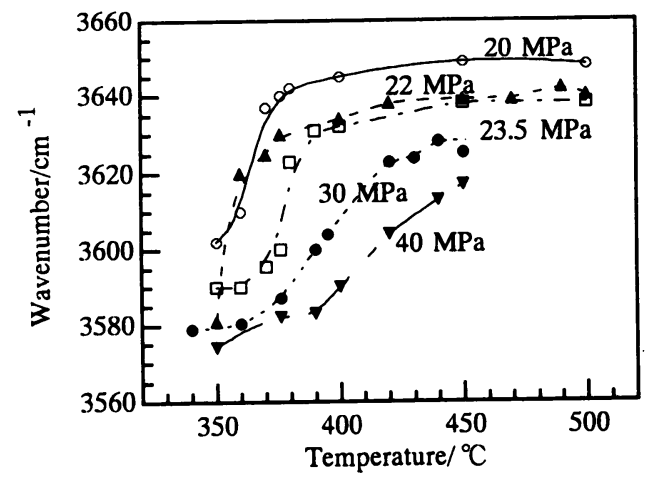

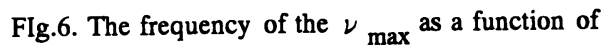
temperature at different pressures. 
$40.0 \mathrm{MPa}$ では max $_{\max } 450{ }^{\circ} \mathrm{C} て ゙ 3618 \mathrm{~cm}-1$ に達するので、 ほぼNHB構造が形成されていると思われる。一方、 $30.0 \mathrm{MPa}$ よ低圧力下では400 ${ }^{\circ} \mathrm{C}$ 越えると3630 $\mathrm{cm}^{-1}$ あるいはそれ以上にレ,が達しほぼ一定になることか ら、NHB構造にくわえてかなりのダイマー（あるいは モノマー）が共存して平衡状態を成している可能性が 強い。

\section{2 O-H变角振的}

Fig. 7に30.0 MPaでの1645 $\mathrm{cm}^{-1}$ のO-H変角振動（ $\nu_{2}$ ）のラマンスペクトルの温度依存性を示した。このレ 2 モードは300 品以下では温度、压力に依存しないこと が報告されていた [18] が、本研究でのラマンデータ により、そのラマン強度が臨界温度付近で著しく減少 し、400 韋以上では全く検出されない（本稿 2.2 節 に示した操作条件下）ことが明らかになった。また、 $\nu_{2}$ 強度は、 $\nu_{1}$ のそれと異なり臨界温度付近で増加し ない。このような挙動は、四面体構造の消失により、 たとえばダイマーやモノマーの出現がレ 2 振動を妨げて いるのかもしれない。

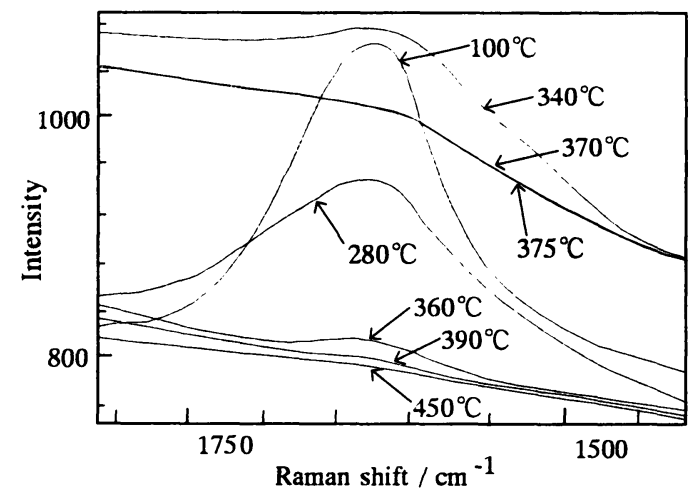

Fig.7. Raman spectra in the-OH-bending vibration for $\mathrm{H}_{2} \mathrm{O}$ at various temperature at $30 \mathrm{MPa}$.

\section{3 水素結合橅造の推察}

Fig. 6に示した臨界点付近での四面体構造を形成する 分子数の顕著な増加は、この領域特有の構造的なゆら ぎに起因しているのかもしれないが、今後、詳細な検 討が必要である。加えて、臨界点付近では ${ }_{1}$ 振動数は ダイマーや自由に回転するモノマーにアサインされる 振動数（タタイマー構造の振動数は3652 $\mathrm{cm}^{-1}$ に、モ） マー構造のそ机は3656.6 $\left.\mathrm{cm}^{-1}[12 、 13]\right)$ に非常に近 接してくるので、Fig.8に示したように臨界点付近で
は、不安定で短寿命な四面体構造がダイマー（あるい はモノマー）と共存し、平衡状態を形成しているもの と考察された。

本研究で、臨界点付近あるいはそれ以上の高温下で 水素結合の一部が消失することが明らかになったか、、 $40 \mathrm{MPa} 、 510{ }^{\circ} \mathrm{C}$ の超臨界状態でも水素結合が存在する ことが確かめられた。

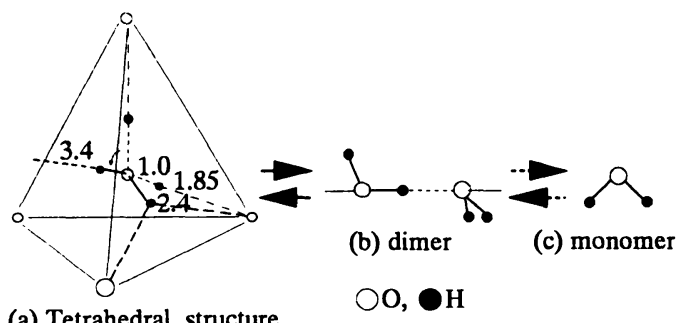

(a) Tetrahedral structure

FIg.8. Structures showing the orientation of $\mathrm{O}-\mathrm{H}$ groups.

\section{5.おわりに}

新たに開発した高温・高圧レーザーラマン分光シス

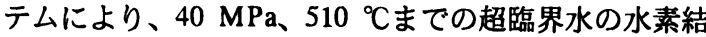
合構造を中心に検討した。その結果、臨界点付近では 四面体構造が壊れ、ダイマーあるいはモノマー構造も 共存している可能性が強いことが明らかになった。さ らに高圧力下では、多少の構造変化は起こるが、臨界 温度以上でも四面体構造は維持されていることも分 かった。

超臨界二酸化炭素同様、超臨界水を反応場とする原 子組み替え反応においてもいくつかの特異な現象が見 いだされ始めており、本研究結果がその解明に役立つ ことを期待するものである。

\section{考考文触}

[1] K. Hatakeda, Y. Ikushima, N.Saito, S.Ito, and O.Sato: Chem. Lett., in press(1997), "Supercritical water oxidation of a PCB of 3-chlorobiphenyl using hydroge peroxide".

[2] 畑田清隆、生島 豊、斉藤功夫、伊東祥太、佐藤 修:特許第2590421号（1996）、"芳香族塩素化合物の 分解方法".

[3] P.E.Savage, S. Gopalan, T.I. Mizan, C.J. Martino, and E.E. Brock:AIChE J., 41, 1723-1778(1995)," Reactions at supercritical conditions: Applications and 
fundamentals".

[4] 斎藤正三郎:「超臨界流体の科学と技術」、三共 ビジネス、1996年.

[5] S.Gopalan and P.E. Savage: J. Phys. Chem., 98, 12646-12652(1994)," Reaction mechanism for phenol oxidation in supercritical water".

[6] Y.Ikushima, N.Saito, M.Arai, and H.W. Blanch:J. Phys. Chem., 99, 8941-8944(1995)," Activation of a lipase triggered by interactions with supercritical carbon dioxide in the near-critical region".

[7] J.B.Ellington and J.F. Brennecke:J. Chem. Soc. Chem. Commun.,1094-1095(1993),"Pressure effect on the esterification of phthalic anhydride in supercritical $\mathrm{CO}_{2} "$.

[8] Y.Ikushima, N.Saito, and M.Arai:J. Phys. Chem., 96, 2293-2297(1992),"Supercritical carbon dioxide as reaction medium: Examination of its solvent effects in the near-critical region".

[9] A.H.Narten and H.A. Levy:J.Chem.Phys., 55 , 22632269(1971),"Liquid water: Molecular correlation functions from X-ray diffraction".

[10] A.Adachi, H.Kiyoyama, M.Nakahara, Y.Masuda, H.Yamatera, A.Shimizu, and Y.Taniguchi:J. Chem. Phys.,90,392-399(1989),"Raman and nuclear magnetic resonance studies on the concentration dependence of orientational relaxation times of the nitrate ion in dilute aqueous solution".

[11] D.A.Masten, B.R.Foy, D.M. Harradine, and Dyer: J.Phys. Chem.,97,8557-8559(1993),"In situ Raman spectroscopy of reactions in supercritical water".
[12] G.P.Ayers and A.D.E. Pullin:Spectrochim. Acta, 32 A,1629-1639(1976),"The i.r. spectra of matrix isolated water species-I. assignment of bands to $\left(\mathrm{H}_{2} \mathrm{O}\right)_{2},\left(\mathrm{D}_{2} \mathrm{O}\right)_{2}$ and HDO dimer species in argon matrices".

[13] M.A.Buldakova and I.I. Matrosov:J. Appl. Spectrsc., 44, 42-45(1986),"Raman spectra of small water clusters". [14] G.E.Walrafen and Y.C. Chu:J. Phys. Chem.,99 11225-11229(1995),"Linearity between structural correlation length and correlated-proton Raman intensity from amorphous ice and supercooled water up to dense supercritical steam".

[15] R.H.Tromp, P. Postorino, G.W.Neilson, M.A. Ricci, and A,K, Soper: J. Chem. Phys.,101,62106215(1994)," Neutron diffraction studies of $\mathrm{H}_{2} \mathrm{O} / \mathrm{D}_{2} \mathrm{O}$ at supercritical temperatures. A direct determination of $\mathrm{g}_{\mathrm{HH}}(\mathrm{r}), \mathrm{g}_{\mathrm{OH}}(\mathrm{r})$, and $\mathrm{g}_{\mathrm{OO}}(\mathrm{r}) "$.

[16] E.U.Franck:J. Solution Chem., 2, 339-356(1973)," Concentrated electrolyte solutions at high temperatures and pressures".

[17] Yu.E.Gorbaty and Yu. N. Demianets:Chem. Phys. Lett., 100, 450-454(1983),"The pair-correlation functions of water at a pressure of $1000 \mathrm{bar}$ in the temperature range 25-500 ${ }^{\circ} \mathrm{C} "$.

[18] C.I.Ratcliffe and D.E.Irish:J. Phys. Chem., 86, 4897-4905(1982),"Vibrational studies of solutions at elevated temperatures and pressures, 5.Raman studies of liquid water up to $300{ }^{\circ} \mathrm{C}$ ".

[1997年2月3日受理 ] 